The meeting in Cambridgo has given ample evidence of the great need for and interest in small conferences, where experience and progress within this rapidly developing field are discussed informally. The method of radiocarbon dating is still new, and further technical improvements are likely to come. On the other hand, its wide range of applicability has not yet been fully understood and appreciated. Thercforc, joint meetings of physicists and chemists with archæologists, geologists and other users of dating results are bound to be mutually instructive and stimulating, provided the groups can be kept small and scientists with as remotely related interests as atomic physics and history of human cultures can discus s the essentials, each making an effort to understand the others' problems. HILDE LevI

\section{ANIMAL PRODUCTION FROM GRASS}

$\mathrm{T}$ HE theme of "Animal Production from Grass" proved a most successful choice for the fifth 'study meeting' of the European Association of Animal Production, which was held at Reading during July. Representatives of seventeen countries were present, and all stayed in two of the University's halls of residence; this contributed on the social side towards the success of the meeting.

As a preliminary to the meeting, most of the visiting European delegates took part in a tour beginning with a visit to the Royal Show at Nottingham, where the Council of the Royal Agricultural Society extended its hospitality to the visitors. Particular interest was shown in the display of British breeds of livestock. Afterwards, visits were made to the research farm at Thurgarton and the Veterinary Research Unit of Messrs. Boots, and to Mr. Maurice Passmore's farm at Wormleighton.

At Reading, the theme for discussion was introduced by two main papers, each being followed by shorter reports on current research in the varions countries. On the first day, Prof. M. M. Cooper, of King's College, Newcastle upon Tyne, delivered the chief contribution on "Animal Management for Intensive Production from Grass". This comprehensive review of the present position in farm practice and in the experimental field was both stimulating and provocative and delivered with characteristic vigour. Prof. Cooper directed attention to the discrepancies that exist between the recorded output from grassland under experimental conditions and that obtained on most farms, even those under more progressive management. For this the farmer must not be judged harshly. Many lack the capital to ensure better utilization, while generally there is a lack of the technical knowledge of how to produce grass with "the composition of a watered concentrate for eight or nine months of the year in sufficient quantities to meet the nutritive demands of highproducing cows"; and there is no simple recipe the adviser can givo the farmer to enable him to do so.

In Britain the well-distributed rainfall and the fact that eighty acres is the size of the typical farm have made the higher efficiency of the dairy cow a dominating factor, and she is the pivot of a system of mixed farming. The meat-producing sheep is important on large arable farms and on the large, preponderantly grass farms of the north, where cattle may be merely mowing machines to keep the grass in good condition for maximum mutton production. One of the current problems is the extent to which sheep can be integrated into dairy farming. Some sheep on a typical large dairy farm are a necessity for proper pasture management; and in establishing a directly re-seeded pasture, they are invaluable in effecting consolidation and controlling weeds in the early stages. Used sensibly, they can augment the quality of grazing for the dairy herd; but in such circumstances, they are essentially scavengers, which is also their proper role on a large arable farm with limited grass.

Prof. Cooper also discussed systems of grazing, pointing out that trials in New Zealand gave better live-weight gains, carcass weights and lamb grading from rotational grazing where the stocking-rates were high than from non-rotational grazing, but that at low rates of stocking the reverse was true. On conservation of grass we have much to learn from Continental countries. Though we should aim at maximum use in situ, with the reduced conservation losses, lower handling costs and better return of animal excrement to maintain fertility, conservation is also essential and is a means as well as an end in intensive pasture management.

Finally, Prof. Cooper appealed for a better assess. ment of nutrient off-talie from pasture. It is absurd to credit full value to concentrates and other foods of known analysis, leaving grass and grass products to carry all the errors of estimate. Such a system, now current, discounts the value of grassland under a system where both grass and concentrates are fed, and makes intensive grassland management appear less efficient than it actually is.

The first of the subsidiary papers was by Dr. W. Holmes and D. S. MacLusky, of the Hannah Dairy Research Institute. They reviewcd the effects of pasture management methods on the production and feed consumption of dairy cows in trials on the Institute's farm. Production per acre was in many cases the final objective, and for this purpose maximum herbage consumption per cow might not be the best policy, as it might be obtained at the expense of efficient food conversion. Possibly slightly more mature herbage than the ideal may sustain more cattle per acre with only negligible reduction in yields per cow. Provided weather and good management ensure a constant supply of good grass, the strip-grazing method without cutting the grass or providing supplementary feed appear to give the most satisfactory results.

In a report of "A Comparison of Systems of Sheep Grazing Management" carried out at Wye College, Kent, H. Cornforth dealt with two sheep-grazing trials. Where nitrogenous fertilizers were used, rotational grazing gave the best utilization. Three days appeared to be the maximum that fattening sheep should remain on each plot. Gang-mowing had an advantage under continuous grazing where no nitrogenous fertilizer was used, but not where nitrogen was applied. Rotational grazing of a sward treated with nitrogen gave almost $700 \mathrm{lb}$. live-weight gain per acre, which is 27 per cent better than from a continuous grazing treatment on the same light chalk soil.

Other papers in this section were from Yugoslavia, Germany, The Netherlands, Austria, Portugal and Switzerland. That from P. B. De Boer, a Netherlands farmer, outlined his methods of intensive grassland farming, designed to try to eliminate the estimated 
33 per cent loss of grown herbage in the process of grazing and conservation. This is done by strip grazing for limited periods and housing the cows at night. Each field is cut or grazed five or six times per season, nitrogenous fertilizer being applied following each cut or grazing period. By alternating cutting and grazing, palatability is improved. Dung is only applied to fields the crops of which are to be cut for silage the following season. The yield of cows shows that grass grown in September or October is not so productive of milk as that grown earlier in the summer. Starchy foods are used to balance the grass and give better utilization.

The second session of the meeting was devoted to the "Agronomic and Physiological Considerations governing Grassland Utilization". For this subject the principal paper was in two parts, the first on the physiological aspects being given by A. M. Frens, of The Netherlands State Agricultural Experiment Station at Hoorn, while the second, on the economic principles of grassland farming, was given by $\mathrm{H}$. Dijkstra, of The Netherlands Agricultural Economics Research Institute.

Mr. Frens, in a clear and persuasive paper, pointed out the difficulties with which cattle on intensively managed pasture have to contend in dealing with the physical structure and high moisture content of young tender grass on which they are expected to live for long periods. Where the feed is low in fibrous and stemmy components, it tends to pack too closely in the rumen, and optimal microbial activity does not develop. This may lead in extreme cases to a deficiency of those nutrients of microbial origin which are essential to the animal's well-being. Not only so, but also the large quantities of water that have to be dealt with by animals living on luscious young grass strain their resorptive capacity, and water resorption from the intestines may be less effective than it physiologically should be. This results in soft fæces, in which an excess of minerals is excreted. Cattle which are scouring, moreover, tend to have a greater sodium and copper requirement, and the grass may contain insufficient to meet the extra demand caused by the increased loss by excretion. Supplementary food to give additional fibre to cattle on highly stimulated pastures can be an advantage, even if the grass contains all the nutrients needed for the animal's level of production. It should be chosen carefully, so that it does not prevent a high intake of grass, and the inclusion of extra sodium, copper and perhaps magnesium may be worth while.

Mr. Dijkstra's paper was the only one dealing with economic aspects. He laid down three conditions that must be fulfilled for the most economical production: (a) grass and grass products must be adapted, in the most economical way and along with any purchased feeding-stuffs, to the feeding require. ments of the farm livestock ; $(b)$ the farm equipment, soeds, fertilizers and labour used must be so applied that no greater net output could be obtained by utilizing them in any other line of production; and (c) the primary products of the enterprise (grassland products) must be converted as efficiently as possible into the secondary products (milk, meat, etc.). These three conditions are not independent of each other, but have a mutual influence.

There were twelve subsidiary papers in this session, of which two were contributed from the United Kingdom. W. F. Raymond, of the Grassland Research Station, reviewed the problems involved in the "Estimation of Herbage consumed by Grazing
Stock". At the Grassland Research Station, as in New Zealand, the fæcal index method is being developed. It is felt that this method is likely to give greater accuracy than others being tried in America; and that from it an estimate of the grazing intake can be made and a measure of the herbage quality obtained. While the technique is simple to operate, it is dependent on adequate sampling, and to this greater attention has still to be given. J. L. Corbett, of the Rowett Research Institute, dealt with "Some Aspects of the Nutrition of Grazing Dairy Cows" and gave details of trials in which the effects of supplementary foods on herbage intake were studied.

Other contributions were from France, Portugal, Switzerland, Belgium, Germany, The Netherlands, Finland and Italy. Dr. L. Seekles, of The Netherlands, dealt with grass or lactation tetany, to which he prefers to give the name 'nutrition tetany'. He criticized the suggestion frequently made that intensively fertilized pasture is a prime cause, since it may occur both on lush pastures and in stall-fed cattle. In addition to the visible symptoms of tetany, there is also gastro-intestinal disfunction. It is possible that certain poisons of intestinal origin interfere with the magnesium-regulating centre in the brain, causing a shift of magnesium from the blood to the tissues. This may be initiated by abnormal functioning of the digestive tract due to its overburdening with excessive food, whether it be lush pasture or other foods. More than one contributor directed attention to the importance of developing the correct bacterial flora for the best digestive utilization of silage. Invariably, animals to which silage is introduced make little or no progress for some time, though later they may recover the lost ground. This appears to be due to the time taken for the correct bacteria for digestion of silage to develop. Further study of this aspect of digestion and of the best utilization of various forages is needed.

A characteristic of both sessions was the vigorous discussion, which was ably directed by the president, Prof. A. M. Leroy. The meeting concluded with the adoption of a resolution calling for intensified research on international lines on the problems of producing a high yield of good-quality grass and of its utilization. There is still, except in some circumstances, a failure to use the full potentiality of the grass crop.

A. R. WANNOP

\section{INSTITUTE OF MEDICAL LABORATORY TECHNOLOGY}

\section{SEVENTH TRIENNIAL CONFERENCE}

$\mathrm{T}$

HE seventh triennial conference of the Institute of Medical Laboratory Technology was held in the University of Nottingham during August 29September 2. In opening the conference, Dr. G. E. Godber, joint deputy chief medical officer to the Ministry of Health, spoke on the development of the pathology services in Great Britain. $\mathrm{He}$ began, appropriately, by showing the build-up of laboratory services in the North Midland Region since the beginning of the Second World War, during which the Emergency Pathology Service became the forerunner of the existing network. In spite of war-time improvements, the pathological services over the whole country were far short of requirements when the National Health Service took over in 1948. 